\title{
Wood molasses as a preservative for high moisture barley. 3. Feeding value for growing cattle
}

\author{
PEKKA HUHTANEN \\ Department of Animal Husbandry, University of Helsinki, \\ SF-00710 HELSINKI 71, Finland
}

\begin{abstract}
In two experiments the feeding value for growing cattle of barley ensiled with wood molasses ( $55 \%$ DM) was compared with dried barley (DB) and barley ensiled with AIV II solution (AIVB). Wood molasses was applied at levels of 8 (WMB8) or $16 \%$ (WMB16) of barley DM in Exp. 1 and $12 \%$ (WMB12) of barley DM in Exp. 2. The AIV II solution was used at a level of $0.3 \% \mathrm{v} / \mathrm{w}$. In Exp. $1 \mathrm{DB}$ and WMB8 were compared during period 1 and DB and WMB16 during period 2. AIVB and WMB12 were compared in Exp. 2. Experiment 1 was performed with 12 and Exp. 2 with 16 animals of Ayrshire and Friesian breed. The average ages of the animals at the beginning of the experiment were 126 and 100 days. The first period in Exp. 1 lasted 45 days and the second 53 days. Experiment 2 lasted 140 days.

The feeding was based on barley, soybean meal and hay in Exp. 1 and on barley, rapeseed meal and grass silage in Exp. 2 and daily gain of $1200 \mathrm{~g} / \mathrm{d}$ was targeted. The average proportion of barley of total DM intake averaged $61 \%$ during period 1 and $59 \%$ during period 2 of Exp. 1 and $54 \%$ in Exp. 2. The corresponding proportions of forage of DM intake were 27,32 and $37 \%$.

The average daily gains of 1107 and $1178 \mathrm{~g}$ for DB and WMB8, 1182 and $1129 \mathrm{~g}$ for DB and WMB16 and 1248 and $1251 \mathrm{~g}$ for AIVB and WMB12 were not significantly different. Nor did the groups show any significant differences in feed conversion rate, carcass characteristics and rumen fermentation except the lower $(\mathrm{P}<0.05)$ dressing percentage of the WMB16 group in Exp. 1. Plasma urea $\mathrm{N}$ was higher $(\mathrm{P}<0.01)$ and cholesterol lower $(\mathrm{P}<0.01)$ in the AIVB group than in the WMB12 group. Plasma concentrations of glucose, alanine aminotransferase, asparte aminotransferase and creatinine did not differ significantly in the different groups.
\end{abstract}

\section{Introduction}

With the recent rising energy costs, chemical preservation of high moisture grain has gained attracting attention as an alternative to drying. The advantages and disadvantages of such systems of cereal preservation have been presented in reviews by Merrill (1971) and Jones et al. (1974). One major advantage is the possibility of early harvest, an advantage of special importance to Northern and Central Finland, where the growing season is short. The losses in the field can be 
reduced with earlier harvesting, and higher yields obtained if later varieties and a higher level of $\mathrm{N}$-fertilization can be used.

Merrill (1971) and Jones et al. (1974) have reported that feeding ensiled or acidtreated grain results in weight gain and feed efficiency values that are equal or slightly better than those for dried grain. KRALL (1967), summarizaing research carried out in Britain, reported that steers fed high moisture barley had higher daily gain and feed efficiency than those fed dried barley. PoutIAINEN et al. (1973) did not find any differences in daily gain and feed efficiency between barleys ensiled with various additives and dried barley. Korhonen et al. (1973) reported a lower grass silage intake with formic acid ensiled barley compared with dried or propionic acid-treated barley. However, in daily gain and feed efficiency there were no differences between the groups.

Wood molasses, a by-product of the wood processing industry, has been shown to be an efficient preservative for high moisture barley and slightly to improve nitrogen utilization in sheep, but it decreased the digestibility of DM and OM used at a level of $16 \%$ of barley DM (SAlo 1978, Huhtanen 1984 a). A number of different by-products of the wood processing industry have been used for growing cattle (KLopfenstein 1973, Chang et al. 1977, WAHLBerg and CASH 1979) and for sheep (Williams et al. 1969, Groyle et al. 1975) resulting in equal or slightly poorer feed utilization compared with control diet or cane molasses.

The objective of the present investigation was to compare the performance of growing cattle fed wood molasses ensiled barley with that of cattle fed barley ensiled with AIV II solution and to discover whether wood molasses has any detrimental effects when used at higher levels.

\section{Material and methods}

Two feeding trials were conducted, using 8 bulls and 4 heifers (Exp. 1) and 16 bulls
(Exp. 2). The animals were Ayrshire, Friesian or Friesian crosses. In both experiments the animals were divided into two groups, similar in respect of sex, breed, age, birth weight and live weight. Experiment 1 was divided into two periods. During the first period of 45 days, dried barley (DB) was compared with barley ensiled with wood molasses at a level of $8 \%$ of barley DM (WMB8), and during the period of 53 days dried barley was compared with barley ensiled with $16 \%$ wood molasses (WMB16). After period 1 the animals fed WMB8 were transferred to WMB16 diet and the animals fed DB continued with the same diet. In Exp. 2, barleys ensiled with $0.3 \% \mathrm{v} / \mathrm{w}$ of AIV II solution (80\% formic acid, $2 \%$ ortophosphoric acid) (AIVB) or 12 of $\%$ of wood molasses of barley DM (WMB12) were compared. Experiment 2 lasted 126 days for Ayrshire bulls and 154 days for other animals. The ensiled barleys were the same as used in preservation and metabolism trials (HUHTANEN $1984 \mathrm{a}, \mathrm{b}$ ). At the beginning of the experiment the average age and weight of the animals were 126 $\mathrm{d}$ and $163 \mathrm{~kg}$ in Exp. 1 and $100 \mathrm{~d}$ and 122.5 $\mathrm{kg}$ in Exp. 2. The animals were weighed at the beginning and end of the experiments on two consecutive days and during the experiment every second week.

\section{Feeds and feeding}

In Exp. 1 the animals received baled hay as forage and soybean meal to meet the requirements for DCP. The lower crude protein contents of WMB8 and WMB16 were adjusted with soybean meal. Grass silage was used as forage in Exp. 2 and rapeseed meal as protein concentrate. The lower crude protein content of WMB12 was not compensated in this experiment. Barley was fed equally on DM basis and a commercial mineral supplement was provided at $100 \mathrm{~g} / \mathrm{d}$. A protein and mineral supplement was mixed with barley prior to feeding. The animals were fed individually twice daily in both experiments. The feeding was designed to sustain a growth 
rate of $1200 \mathrm{~g} / \mathrm{d}$ for bulls, according to Finnish standards.

The feeds were sampled once a week and pooled into one sample for two weeks for forages and barleys and into one sample for four weeks for protein concentrates. DM determination was made of every sample and feed analysis of the pooled samples. Samples were prepared as described by HuHTANEN (1984 a) and the feed analysis according to standard methods. In vitro digestibility of grass silage was made by the method of TILLEY and TERRY (1963) Feed refusals were weighed each day.

Blood samples were taken from Vena jugularis at the beginning of Exp. 2 and at four week intervals thereafter, before the morning feeding. The samples were pre treated, and haemoglobin, haematocrit and plasma glucose were determined by the methods described by NÄsı (1979). Plasma proteins, urea $\mathrm{N}$, alkaline phosphatase (AP), alanine aminotransferase (ALAT), asparte aminotransferase (ASAT), total bilirubine, cholesterol, and creatinine were determined with the analyzer of the GILFORD SYSTEM 3500 (Gilford Instrument Laboratories Inc., USA) in the College of Veterinary Medicine to evaluate the effect of wood mo- lasses as a grain preservative on protein metabolism and on liver and kidney function.

The rumen contents were sampled from different parts of rumen of eight bulls immediately after slaughter. The $\mathrm{pH}$ was measured immediately and VFA were determined from frozen pre treated samples by gas chromatography according to HuIDA (1973).

The differences between the groups were tested by two-way analysis of variance.

\section{Results and discussion}

Feed intake and feed composition

The average chemical composition, calculated energy and DCP values of the feeds are given in Table 1. The chemical composition and quality of grass silage varied widely during the experiment. The quality and mineral composition of the ensiled barleys have been presented in a previous paper (HUHTANEN 1984 a). The average in vitro digestibility of grass silage was $68.2 \%$.

In total DM intake and nutrient consumption there were no differences between the groups (Table 2). The average DCP contents of ration DM were 12.7, 12.7, 11.4 and $11.4 \%$ for DB, WMB8, DB and WMB16

Table 1. Chemical composition and feed values of experimenta feeds.

\begin{tabular}{|c|c|c|c|c|c|c|c|c|c|}
\hline & \multirow{2}{*}{$\begin{array}{c}\text { Dry } \\
\text { matter } \\
\%\end{array}$} & \multicolumn{5}{|c|}{ In dry matter, $\%$} & \multicolumn{3}{|c|}{ Feed values } \\
\hline & & Ash & $\begin{array}{c}\text { Crude } \\
\text { prot. }\end{array}$ & $\begin{array}{l}\text { Ether } \\
\text { extr. }\end{array}$ & $\begin{array}{l}\text { Crude } \\
\text { fibre }\end{array}$ & NFE & $\begin{array}{c}\text { FFU/ } \\
\text { kg DM }\end{array}$ & $\begin{array}{c}\text { ME MJ/ } \\
\text { kg DM }\end{array}$ & $\begin{array}{l}\text { DCP g/ } \\
\mathrm{kg} \text { DM }\end{array}$ \\
\hline \multicolumn{10}{|l|}{ Exp. 1} \\
\hline Hay & 86.9 & 6.1 & 10.5 & 2.2 & 32.6 & 48.5 & 0.58 & 9.1 & 64 \\
\hline Dried barley & 87.4 & 3.0 & 12.3 & 2.2 & 5.9 & 76.6 & 1.13 & 13.3 & 90 \\
\hline WMB8 & 57.4 & 4.0 & 11.9 & 2.6 & 5.6 & 76.0 & 1.11 & 13.0 & 86 \\
\hline WMB16 & 55.9 & 4.6 & 11.4 & 2.4 & 5.2 & 76.4 & 1.07 & 12.6 & 75 \\
\hline Soybean meal & 87.5 & 7.0 & 51.2 & 1.2 & 7.3 & 33.4 & 1.11 & 12.9 & 452 \\
\hline \multicolumn{10}{|l|}{ Exp. 2} \\
\hline Silage & 23.6 & 8.2 & 16.6 & 6.2 & 29.8 & 39.3 & 0.75 & 9.9 & 125 \\
\hline AIVB & 57.1 & 2.6 & 14.0 & 2.6 & 6.0 & 74.5 & 1.11 & 12.9 & 101 \\
\hline WMB12 & 53.6 & 3.4 & 13.1 & 2.7 & 5.7 & 75.1 & 1.07 & 12.5 & 93 \\
\hline Rapeseed meal & 88.6 & 7.8 & 37.4 & 4.2 & 14.0 & 36.6 & 0.99 & 11.4 & 310 \\
\hline
\end{tabular}

$\mathrm{FFU}=0.7 \mathrm{~kg}$ starch

Silage: $\mathrm{pH} 3.80$, lactic acid $7.9 \%$, acetic acid $2.0 \%$, propionic acid $0.1 \%$ of $\mathrm{DM}, \mathrm{NH}_{3}-\mathrm{N} 6.0 \%$ of total N 
diets, respectively, in Exp. 1, and 13.0 and $12.5 \%(\mathrm{P}<0.05)$ for AIVB and WMB12 diets, respectively, in Exp. 2. The proportion of forage of the total DM was $26.6 \%$ during the first period and $31.6 \%$ during the second period in Exp. 1, and $36.7 \%$ in Exp. 2. The palatability of WMB8 tended to be better than that of dried barley and DM intake per $\mathrm{kg} \mathrm{W}^{0.75}$ higher. The animals fed ensiled barley consumed their concentrate faster than those fed DB, in agreement with the results reported by MERRILl (1971). In contrast, Rissanen and Ettala (1977) have reported lower intake of ensiled and propionic acid-treated barley compared to dried barley in dairy cows fed grass silage ad libitum. The forage intake was same on WMB8 and WMB16 than on DB diet. In some experiments (McCaffree and Merrill 1968, McCAFrree et al. 1971, Ingalls et al. 1974), ensiled grain has decreased the forage intake in dairy cows. According to Merrill (1971) the lower forage intake with ensiled grain has mainly been found when the proportion of concentrate was over $50 \%$ of total DM intake.

There were no significant differences in growth rate, feed conversion or carcass characteristics except for the lower $(\mathrm{P}<0.05)$ dressing percentage with WMB16 than DB ration (Table 3). However, the growth rate tended to be higher on WMB8 and lower on WMB16 than on DB. This agrees with the effect of the level of wood molasses in ration digestibility in sheep (HuHTANEN 1984 b). The difference between the DB and WMB16 groups may partly be explained by the abrupt change from lower to higher level of wood molasses, because the difference in daily gain was highest at the beginning of the second period. The slightly higher soybean meal level in WMB8 ration than in DB ration may not have affected the growth rate because the crude protein intake was higher than suggested for growing cattle (ANDERSEN and JuST 1979, RoHr 1980). However micro-

Table 2. The average feed intake (kg DM/d) and nutriet consumption

\begin{tabular}{|c|c|c|c|c|c|c|c|c|}
\hline \multirow[t]{3}{*}{ Experiment 1} & \multicolumn{4}{|c|}{ Period 1} & \multicolumn{4}{|c|}{ Period 2} \\
\hline & \multicolumn{2}{|c|}{ DB } & \multicolumn{2}{|c|}{ WMB8 } & \multicolumn{2}{|c|}{ DB } & \multicolumn{2}{|c|}{ WMB16 } \\
\hline & $\bar{x}$ & s.d. & $\bar{x}$ & s.d. & $\bar{x}$ & s.d. & $\bar{x}$ & s.d. \\
\hline Hay & 1.22 & 0.24 & 1.25 & 0.32 & 1.89 & 0.49 & 1.85 & 0.60 \\
\hline Barley & 2.72 & 0.36 & 2.86 & 0.37 & 3.43 & 0.39 & 3.43 & 0.37 \\
\hline Soyabean meal & $0.54^{a}$ & 0.03 & $0.57^{\mathrm{b}}$ & 0.03 & $0.49^{d}$ & 0.02 & $0.57^{e}$ & 0.02 \\
\hline Total DM & 4.48 & 0.56 & 4.68 & 0.66 & 5.81 & 0.84 & 5.85 & 0.94 \\
\hline $\mathrm{DM} \mathrm{g} / \mathrm{kg} \mathrm{W}^{0.75}$ & $88.5^{\mathrm{d}}$ & 1.8 & $92.9^{c}$ & 1.5 & 93.8 & 4.2 & 94.5 & 3.4 \\
\hline FFU/d & 4.39 & 0.51 & 4.54 & 0.56 & 5.55 & 0.69 & 5.39 & 0.71 \\
\hline $\mathrm{ME} \mathrm{MJ/d}$ & 54.1 & 4.7 & 56.1 & 7.3 & 69.1 & 9.2 & 67.4 & 9.7 \\
\hline DCP g/d & 565 & 34 & 589 & 39 & 656 & 54 & 640 & 55 \\
\hline \multirow[t]{2}{*}{ Experiment 2} & & \multicolumn{3}{|c|}{ AIVB } & & \multicolumn{3}{|c|}{ WMB12 } \\
\hline & & $\bar{x}$ & & s.d. & & $\bar{x}$ & & s.d. \\
\hline Silage & & 1.77 & & 0.27 & & 1.79 & & 0.28 \\
\hline Barley & & 2.51 & & 0.26 & & 2.54 & & 0.26 \\
\hline Rapeseed meal & & 0.41 & & 0.09 & & 0.41 & & 0.09 \\
\hline Total DM & & 4.69 & & 0.44 & & 4.74 & & 0.44 \\
\hline DM g/ $\mathrm{kg} \mathrm{W} W^{0.75}$ & & 86.3 & & 1.3 & & 87.7 & & 1.8 \\
\hline FFU/d & & 4.51 & & 0.40 & & 4.46 & & 0.39 \\
\hline $\mathrm{ME} \mathrm{MJ/d}$ & & 54.8 & & 5.0 & & 54.3 & & 4.9 \\
\hline DCP $g / g$ & & 604 & & 27 & & 588 & & 21 \\
\hline
\end{tabular}

Means with different letters significantly different: $a, b,(P<0.05)$, d, e $(P<0.01)$ 
bial protein cannot satisfy the whole protein requirement of rapidly growing cattle at live weight below $200 \mathrm{~kg}$ (Roy 1980).

The effect of wood molasses was similar that reported by others. CRAWFORD et al. (1978) found the feeding value of wood molasses from the Masonite process to be equal to cane molasses at a level of $10 \%$ in the diet. When spent sulphite liquor (SSL) was fed at levels of 8 and $12 \%$ on DM basis, no differences were detected between SSL groups and the control (CHANG et al. 1977). Wood molasses of the kind used in this experiment tended to improve live weight gain when it was fed unneutralized in hay and barley based diets (TẢNG 1979). Ca- and $\mathrm{NH}_{3}$-neutralized wood molasses had no effect on live weight gain. KLOPFENSTEIN (1973) reported spent sulphite liquor to decrease live weight gain when it was used at higher levels.

Calculated NE values of wood molasses were highest at the levels of $8-12 \%$ of barley DM and were equal to beet molasses. Also Chalupa and Montgomery (1979) found the NE values of wood molasses and cane molasses to be equal the NE values of grain and to be higher when they were replacing no more than $5 \%$ of grain.

The present results describing the effect of preserving method on daily gain and feed conversion agree with earlier reports (FORSYTH et al. 1972, Macleod and Mowat 1974, Flipot and Pelletier 1980). Poutiainen et al. (1973) found no differences in daily gain and feed conversion between dried barley and barley ensiled with formic, acetic or propionic acid or with formaldehyde containing additive. The change in the protein fraction during storage from an insoluble to a highly soluble form had no adverse effect on the performance of growing animals. According to Little et al. (1963) and Prigge et al. $(1976,1978)$, protein utilization can be improved through rumen degradation and conversion to microbial protein when the dietary protein is of poor quality.

\section{Rumen fermentation}

There were no significant differences between AIVB and WMB12 groups in rumen $\mathrm{pH}$, the total VFA concentration or VFA ratios (Table 4). The small differences observed were similar to those found in sheep fed the same barleys on hay based diet (HuH TANEN 1984b), but total concentration of VFA was clearly higher in bulls. It could be expected from the effect of ensiled barley on VFA ratios observed in sheep (HUHTANEN

Table 3. Live weight, daily weight gain, feed conversion rate and carcass characteristics

\begin{tabular}{|c|c|c|c|c|c|c|}
\hline & \multicolumn{4}{|c|}{ Experiment 1} & \multicolumn{2}{|c|}{ Experiment 2} \\
\hline & \multicolumn{2}{|c|}{ Period 1} & \multicolumn{2}{|c|}{ Period 2} & \multirow[b]{2}{*}{ AIVB } & \multirow[b]{2}{*}{ WMB12 } \\
\hline & DB & WMB8 & DB & WMB16 & & \\
\hline Number of animals & 6 & 6 & 6 & 6 & 8 & 8 \\
\hline Days in trial & 45 & 45 & 53 & 53 & 140 & 140 \\
\hline Initial weight, kg & 163.5 & 162.5 & 213.3 & 215.5 & 122.6 & 122.4 \\
\hline Final weight, kg & 213.3 & 215.5 & 276.0 & 275.3 & 297.4 & 297.5 \\
\hline $\begin{array}{l}\text { Daily gain, } \mathrm{g} \\
\text { Feed conversion rate }\end{array}$ & 1107 & 1178 & 1182 & 1129 & 1248 & 1251 \\
\hline FFU/kg gain & 4.07 & 3.96 & 4.69 & 4.79 & 3.66 & 3.61 \\
\hline Age at slaughter, d & & & 224 & 224 & 258 & 260 \\
\hline Slaughter weight, kg & & & 276.0 & 275.3 & 323.3 & 332.5 \\
\hline Carcass weight, kg & & & 142.2 & 138.7 & 169.5 & 173.3 \\
\hline Dressing $\%$ & & & $51.5^{\mathrm{a}}$ & $50.4^{b}$ & 52.3 & 52.1 \\
\hline
\end{tabular}

Means with different letters significantly different: $a, b(P<0.05)$ 
1984 b) that energy utilization for growth would be lower when ensiled barley was fed to growing cattle. Such was not observed, however, in this or in many other experiments (Merrill 1971, Poutiainen et al. 1973, Korhonen et al. 1973).

The number of protozoa in the rumen contents tended to be higher on WMB12 diet, but no differences were found in the number of bacteria in microscopic studies.

Blood composition and health of the animals

Plasma urea $\mathrm{N}$ level was higher $(\mathrm{P}<0.01)$ with AIVB than with WMB12 (Table 5). However, there were no differences in rumen ammonia level or degradation rate of nitro- gen in the rumen in sheep fed AIVB or WMB12 on hay based diet (HuHTANEN 1984 b). Thornton (1970) suggested that urea excretion in urine depends on the plasma urea level. Sheep fed barley ensiled with wood molasses produced less urinary nitrogen than sheep fed dried barley (HuHTANEN 1984 b). One possible explanation for the lower plasma urea level on WMB12 diet may be an increased carbohydrate fermentation in caecum or colon. The required nitrogen is derived from blood (Nolan and Stachiw 1979) and the nitrogen excreted in faeces increases, while that excreted in urine decreases (ØRSKOV et al. 1980).

Plasma cholesterol concentration was higher $(\mathrm{P}<0.01)$ on WMB12 than on AIVB

Table 4. pH, and VFA in rumen fluid taken after slaughter

\begin{tabular}{|c|c|c|c|c|}
\hline & \multicolumn{2}{|c|}{ AIVB } & \multicolumn{2}{|c|}{ WMB12 } \\
\hline & $\bar{x}$ & s.d. & $\bar{x}$ & s.d. \\
\hline $\mathrm{pH}$ & 5.48 & 0.26 & 5.62 & 0.13 \\
\hline VFA, mmoles/1 & 156.7 & 20.4 & 145.8 & 9.8 \\
\hline \multicolumn{5}{|l|}{ Molar $\%$ of } \\
\hline Acetic acid & 60.3 & 2.1 & 60.7 & 2.6 \\
\hline Propionic acid & 20.1 & 3.3 & 20.1 & 1.6 \\
\hline Butyric acid & 15.0 & 2.9 & 15.0 & 2.9 \\
\hline Isovaleric acid & 2.2 & 0.7 & 1.8 & 0.3 \\
\hline Valeric acid & 2.2 & 0.3 & 2.3 & 0.2 \\
\hline
\end{tabular}

Table 5. The mean concentration of blood constituents during the experiment

\begin{tabular}{|c|c|c|c|c|}
\hline & \multicolumn{2}{|c|}{ AIVB } & \multicolumn{2}{|c|}{ WMB12 } \\
\hline & $\bar{x}$ & s.d. & $\overline{\mathbf{x}}$ & s.d. \\
\hline $\mathrm{n}$ & 44 & & 44 & \\
\hline Haemoglobin, g/1 & 114.6 & 11.5 & 117.6 & 8.1 \\
\hline Haematocrit & 34.1 & 3.7 & 34.3 & 2.5 \\
\hline Plasma glucose, mmol/1 & 5.33 & 0.48 & 5.47 & 0.46 \\
\hline Plasma proteins, $\mathrm{g} / 1$ & 65.8 & 7.0 & 64.5 & 4.3 \\
\hline Albumin, $\mathrm{g} / 1$ & 36.3 & 2.1 & 36.9 & 1.8 \\
\hline Plasma urea $\mathrm{N}, \mathrm{mmol} / \mathrm{l}$ & $2.87^{d}$ & 0.60 & $2.47^{e}$ & 0.68 \\
\hline $\mathrm{AP}, \mathrm{IU} / 1$ & 389 & 130 & 402 & 98 \\
\hline ALAT, IU/1 & 15.4 & 6.7 & 16.3 & 6.0 \\
\hline ASAT, IU/1 & 81.0 & 16.7 & 81.4 & 15.1 \\
\hline Total bilirubin $\mu \mathrm{mol} / 1$ & 1.77 & 0.76 & 1.82 & 0.84 \\
\hline Cholesterol, mmol/1 & $2.68^{\mathrm{d}}$ & 0.68 & $3.13^{e}$ & 0.80 \\
\hline Creatinine, $\mu \mathrm{mol} / 1$ & 89.1 & 15.3 & 85.8 & 13.8 \\
\hline
\end{tabular}

Means with different letters significantly different: $d$, e $(P<0.01)$ 
diet. The effect of dietary factors on cholesterol synthesis has been largely ignored. However, it has been reported in the review by BELL (1981) that feeding sheep with a lipid supplement protected from ruminal degradation caused a substantial increase in cholesterol synthesis in small intestine. The concentrations of liver specific enzymes and creatinine showed no significant differences (Table 5), thus providing no evidence of changes in liver or kidney function due to wood molasses (ANON 1972). CHANG et al. (1977) reported increased concentrations of plasma free phenols of steers fed 8 or $12 \%$ of spent sulphite liquor but no adverse effects were observed in post mortem inspection.

The health of the animals was good with the exception of occasional diarrhoea at the beginning of Exp. 2. The liver of one bull in the AIVB group was rejected due to cirrhosis hepatic.

Acknowledgements. I wish to express my warm thanks Mrs. Eija Latomäki for taking care of the animals and to Doc. Matti Näsi for taking the blood samples.

\section{References}

Andersen, P.E. \& Just, A. 1979. Tabeller over fodermidlers sammansaetning m.m. Det kgl. Lanthusholdningsselskab, Landhusholdningsselskabets Forlag. København. 56 p.

ANON. 1972. Kliiniset laboratoriotutkimukset. 581 p. Porvoo.

BELL, A.W. 1981. Lipid metabolism in liver and selected tissues and in the whole body of ruminant animals. Lipid metabolism of ruminant animals. Ed. Christie, W.W. p. 363-410. Pergamon Press.

Chalupa, W. \& Montgomery, A. 1979. Fermeability of Masonex and cane molasses. J. Anim. Sci. 48: $393-400$.

Chang, F.S., Dryer, I.A. \& Johnson, R.J. 1977. Performance of feedlot cattle and rumen microorganisms as influenced by lignosulphonates $\mathbf{J}$. Anom. Sci. 46: 878-884.

Crawford, D.F., Anthony, W.B. Harris, R.R. 1978. Evaluation of concentrated hemicellulose extract as cattle feed. J. Anim. Sci. 46: 32-40.

Croyle R.C., Long, T.A. \& Hersberger, T.V. 1975. Evaluation of ammonium lignin sulphonate as a nonprotein nitrogen source for sheep. J. Anim. Sci. 40: $1144-1149$.

Flipot, P. \& Pelletier, G. 1980. Influence of methods of conservation on feeding value of high moisture barley fed to dairy steers. Can. J. Anim. Sci. 60: 939-943.

Forsyth, D.M., Mowat, D.N. \& Stone, J.B. 1972. Feeding value for beef and dairy cattle of high moisture corn preserved with propionic acid Can. J. Anim. Sci. 52: 73-79.

Huhtanen, P. 1984 a. Wood molasses as a preservative for high moisture barley. 1. Preservation and digestibility in pig. J. Agric. Sci. Finl. 56: 255-263.

-1984 b. 2 . Ration digestibility and rumen fermentation in sheep. J. Agric. Sci. Finl. 56: 265-274.

HuIDA, L. 1973. Haihtuvien rasvahappojen kvantitatiivinen mäărittäminen pötsinesteestä. J. Scient. Agric. Soc. Finl. 45: 483-488.

Ingalls, J.R., Clark, K.W. \& Sharma, H.R. 1974. Acid-treated high moisture barley for dairy cows. Can. J. Anim. Sci. 54: 205-209.

KRALL, J.L. 1967. Producing, storing and feeding high moisture grain in England. Tech. Bull. Mt. Exp. Sta. No. 625.

Klopfenstein, T.J. 1973. Sulphate liquor in beef cattle rations. J. Anim. Sci. 37: 347. (Abstr.).

Korhonen, I., Poutiainen, E., Tuori, M. \& Lampila, M. 1973. Eri menetelmillä tuoreena säilötty ohra lihanautojen rehuna. 2. Prop-corn-ohra ja muurahaishapolla märkäsăilötty ohra lihanautojen ruokinnassa. Kehittyvă Maatalous 15: 32-41.

Little, C.O., Burroughs, W. \& Woods, W. 1963. Nutritional significance of soluble nitrogen in dietary protein for ruminants. J. Anim. Sci. 22: 358-363.

McCaffree, J.D. Merrill, W.G. 1968. High moisture corn for dairy cows in early lactation. J Dairy Sci. 51: $553-560$.

-, Merrill, W.G. \& Smith, N.E. 1972. Concentrate mixtures based on high moisture ear corn vs. multiingredients for dairy cows in early lactation. J. Dairy Sci. 55: 269-272.

Merrill, D.G. 1971. Feeding high moisture grain silages. Proc. Int. Silage Res. Conf. Washington D.C. p. $156-219$.

Nolan, J.V. \& Stachiw, S. 1979. Fermentation and nitrogen dynamics in Merino sheep given a low-quality roughage diet. Br. J. Nutr. 42: 63-80.

NĀsı, M. 1979. Dried poultry manure as a feed ingre- 
dient for dairy cows. J. Scient. Agric. Soc. Finl. 51 79-148.

Ørskov, E.R., MacLeod, N.A. \& GrubB, D.A. 1980. New concepts of basal $\mathrm{N}$ metabolism in ruminants. Protein metabolism and nutrition. EAAP. Publ. 27. Ed. Oslage, H.J. \& Rohr, K. p. 451-456. Braunschweig.

Poutiainen, E., Korhonen, I., Tuori, M. \& Lampila, M. 1973. Eri menetelmillă tuoreena săilötty vilja lihanautojen ruokinnassa. 1. Lisăaineiden vertailu mărkäsăilönnåssă. Kehittyvă Maatalous 15: 19-31.

Prigge, E.C., Johnson, R.R., Owens, F.N. \& WilliAMS, D.E. 1976. Utilization of nitrogen from ground high moisture and dry corn by ruminants. J. Anim. Sci. 43: 705-711.

-, Galyean, M.L., Owens, F.N., Wagner, D.G. \& Johnson, R.R. 1978. Microbial protein synthesis in steers fed processed corn rations J. Anim. Sci. 46: 249-254.

Rissanen, H. \& Ettala, E. 1977. Säilöviljan käyttő rehuna. Koetoim. ja Käyt. 1977: 42.

RoHR, K. 1980. Meeting the protein requirement of fattening bulls. Proceedings from Paris Beef Prod. European Congress for improved beef productivity.
Reprint. 8 P.

Roy, J.H.B. 1980. Utilization of feed protein. Internordic licentiat/doctorand cource at Helsinki. 15 p.

SALO, M-L. 1978. Puumelassi tuoreviljan săilöntäaineena. J. Scient. Agric. Soc. Finl. 50: 206-211.

THORNTON, R.F. 1970. Factors effecting the urinary excretion of urea nitıogen in cattle. 1. Sodium chloride and water loads. Aust. J. agric. Res. 21: $131-144$.

Tilley, J.M.A. \& Terry, R.A. 1963. A two stage technique for in vitro digestion of forage crops. J. Br. Grassl. Soc. 18: 104-111.

TÁng, L. 1979. Puuteollisuuden jătteet märehtijăn rehuna. Ms. Thesis. 85 p. Helsingin yliopisto, kotieläintieteen laitos.

Wahlberg, M.L. \& CASh, E.H. 1979. Various liquid by-products as a protein supplement to ruminant diet. J. Anim. Sci. 49: 1431-1437.

Williams, D.L., Moore, J.W., Martin, L.C. \& Till. MAN, A.D. 1969. Studies on liquid hemicellulose and cane molasses as carbohydrate sources in urea containing diets of sheep. J. Anim. Sci. 28: 667-672.

Ms received October 12, 1984

\section{SELOSTUS}

\section{Puumelassi tuoreen ohran säilöntäaineena. 3. Puumelassilla säilötty ohra lihanautojen ruokinnassa}

Pekka Huhtanen

Helsingin yliopisto, kotieläintieteen laitos, 00710 Helsinki 71

Tutkimus koostui kahdesta ruokintakokeesta lihanaudoilla, joissa verrattiin puumelassilla (55\% ka) săilöttyä ohraa kuivattuun ohraan (KO) kokeessa 1 ja AIV II-liuoksella säilöttyyn ohraan (AIV2O) kokeessa 2. Puumelassin annostelutasona kãytettiin 8 (PMO8) ja $16 \%$ (PMO16) ohran kuiva-aineesta kokeessa 1 sekă kokeessa $12 \%$ (PMO12) vastaavasti. Koe-eläimină oli kokeessa 112 ja kokeessa 216 vasikkaa, jotka olivat ay-, ja fr-rotua tai fr-risteytyksiă. Kokeessa 1 eläinten ikä oli alussa 126 pv ja elopaino 163 kg sekä kokeessa 2 vastaavasti 100 pv ja 122.5 kg. Kokeen 1 ensimmäinen osa, jossa verrattiin KO:a ja PMO8:a kesti 45, ja toinen osa, jossa verrattiin KO:a ja PMO16:a, 53 päiväă. Koe 2 kesti 140 påivăaa.

Koe-eläimet saivat karkearehuna heinaa (koe 1) tai nurmisäilörehua (koe 2) sekä valkuaistäydennyksenă soijarehujauhetta (koe 1) tai rypsirouhetta (koe 2). Karkearehun osuus kuiva-aineesta oli 27,32 ja $37 \%$ ko- keen 1 I ja II osassa sekä kokeessa 2 sekä ohran 61,59 ja $54 \%$ vastaavasti. Eläimet ruokittiin yksilöllisesti kasvutavoitteena $1200 \mathrm{~g} / \mathrm{pv}$.

Keskimăăräinen päiväkasvu ja ry-kulutus kasvukiloa kohti oli kokeen 1 I osassa $1107 \mathrm{~g}$ ja 4.07 ry KOryhmällă sekä $1178 \mathrm{~g}$ ja 3.96 ry PMO8-ryhmällä, II osassa $1182 \mathrm{~g}$ ja 4.69 ry KO-ryhmällă sekä $1129 \mathrm{~g}$ ja 4.79 ry PMO16-ryhmällă sekä kokeessa 2 AIV2O-ryhmăllă $1248 \mathrm{~g}$ ja 3.66 ry ja PMO12-ryhmällă $1251 \mathrm{~g}$ ja 3.61 ry. Erot eivăt olleet merkitseviă. Myőskaaăn teurastuloksissa ja pötsifermentaatiossa kokeessa 2 ei ollut merkitseviå eroja ryhmien vălillă lukuunottamatta PMO16-ryhmăn alempaa $(\mathrm{P}<0.05)$ teurasprosenttia KO-ryhmăän verrattuna. Plasman ureapitoisuus oli AIV2O-ryhmällă korkeampi $(\mathrm{P}<0.01)$ ja kolesterolipitoisuus alempi $(\mathrm{P}<0.01)$ kuin $\mathrm{PMO12}$-ryhmällă. Plasman glukoosipitoisuudessa sekă maksan ja munuaisten toimintaa kuvaavissa parametreissă ei ollut eroa. 